\title{
TAKSONOMI BLOOM - REVISI RANAH KOGNITIF: KERANGKA LANDASAN UNTUK PEMBELAJARAN, PENGAJARAN, DAN PENILAIAN
}

\author{
Imam Gunawan * \\ Anggarini Retno Palupi **
}

\begin{abstract}
The Cognitive domain of Bloom's taxonomy often serves as a framework for categorizing objectives of education, designing tests, and designing curricula. The taxonomy in order covers: (1) knowledge, (2) comprehension, (3) application, (4) analysis, (5) synthesis, and (6) evaluation. The order has been made use more than fifty years as the basis for education objectives, designing tests and curricula. Revision on the taxonomy is done by changing noun in the taxonomy into verb in the revised taxonomy. This is in order to meet education objectives. Such objectives indicate that students will be able to do something (verb) by using something (noun). Revision by Kratwohl and Anderson resulting the taxonomy: (1) remember, (2) understand, (3) apply, (4) analyze, (5) evaluate, and (6) create.
\end{abstract}

Key words: Revized Bloom's Taxonomy, Cognitive Domain

\begin{abstract}
Abstrak
Taksonomi Bloom ranah kognitif merupakan salah satu kerangka dasar untuk pengkategorian tujuan-tujuan pendidikan, penyusunan tes, dan kurikulum. Tingkatan taksonomi Bloom yakni: (1) pengetahuan (knowledge); (2) pemahaman (comprehension); (3) penerapan (application); (4) analisis (analysis); (5) sintesis (synthesis); dan (6) evaluasi (evaluation). Tingkatan-tingkatan dalam taksonomi tersebut telah digunakan hampir setengah abad sebagai dasar untuk penyusunan tujuan-tujuan pendidikan, penyusunan tes dan kurikulum. Revisi dilakukan terhadap Taksonomi Bloom, yakni perubahan dari kata benda (dalam Taksonomi Bloom) menjadi kata kerja (dalam taksonomi revisi). Perubahan ini dibuat agar sesuai dengan tujuan-tujuan pendidikan. Tujuan-tujuan pendidikan mengindikasikan bahwa siswa akan dapat melakukan sesuatu (kata kerja) dengan sesuatu (kata benda). Revisi dilakukan oleh Kratwohl dan Anderson, taksonomi menjadi: (1) mengingat (remember); (2)
\end{abstract}

* Imam Gunawan adalah Dosen Program Studi PGSD FIP IKIP PGRI Madiun

** Anggarini Retno Palupi adalah Mahasiswa Program Studi PGSD FIP IKIP PGRI Madiun 
memahami (understand); (3) mengaplikasikan (apply); menganalisis (analyze); (5) mengevaluasi (evaluate); dan mencipta (create).

Kata Kunci: Revisi Taksonomi Bloom, Ranah Kognitif

\section{A. Pendahuluan}

Taksonomi ialah klasifikasi atau pengelompokan benda menurut ciri-ciri tertentu. Taksonomi dalam bidang pendidikan, digunakan untuk klasifikasi tujuan instruksional; ada yang menamakannya tujuan pembelajaran, tujuan penampilan, atau sasaran belajar, yang digolongkan dalam tiga klasifikasi umum atau ranah (domain), yaitu: (1) ranah kognitif, berkaitan dengan tujuan belajar yang berorientasi pada kemampuan berpikir; (2) ranah afektif berhubungan dengan perasaan, emosi, sistem nilai, dan sikap hati); dan (3) ranah psikomotor (berorientasi pada keterampilan motorik atau penggunaan otot kerangka). Saat ini dikenal berbagai macam taksonomi tujuan instruksional yang diberi nama menurut penciptanya, misalnya: Bloom; Merill dan Gagne (kognitif); Krathwohl, Martin \& Briggs, dan Gagne (afektif); dan Dave, Simpson dan Gagne (psikomotor).

Tulisan ini akan membatasi pada Taksonomi Bloom yang telah direvisi khususnya pada ranah kognitif, dengan diterbitkannya sebuah buku: A Taxonomy for Learning, Teaching, and Assesing: A Revision of Bloom's Taxonomy of Educatioanl Objectives yang disusun oleh Lorin W. Anderson dan David R. Krathwohl pada tahun 2001. Taksonomi Bloom ranah kognitif merupakan salah satu kerangka dasar untuk pengkategorian tujuan-tujuan pendidikan, penyusunan tes, dan kurikulum di seluruh dunia (Chung, 1994; Lewy dan Bathory, 1994; Postlethwaite, 1994). Taksonomi pendidikan ini terkandung dalam buku The Taxonomy of Educational Objectives The Classification of Educational Goals, Handbook I: Cognitive Domain yang terbit pada tahun 1956 sebagai buah karya dari Benjamin Samuel Bloom (editor), M.D. Engelhart, E.J. Furst, W.H. Hill, dan Krathwohl. Kerangka pikir karya Benjamin Bloom dkk. berisikan enam kategori pokok dengan urutan mulai dari jenjang yang rendah sampai dengan jenjang yang paling tinggi, yakni: pengetahuan (knowledge); (2) pemahaman (comprehension); (3) penerapan (application); (4) analisis (analysis); (5) sintesis (synthesis); dan (6) evaluasi (evaluation).

Satu hal yang penting dalam taksonomi tujuan instruksional ialah adanya hierarki yang dimulai dari tujuan instruksional pada jenjang terendah sampai jenjang tertinggi. Dengan kata lain, tujuan pada jenjang yang lebih tinggi tidak dapat dicapai sebelum tercapai tujuan pada jenjang di bawahnya. Penting pula diingat bahwa tidak terdapat batas yang jelas antara ranah yang satu dengan lainnya. Sebagai contoh, misalnya rumusan tujuannya dalam ranah kognitif penerapan (application); tetapi seringkali tujuan kognitif ini disertai praktik yang memerlukan keterampilan motorik, demikian pula, misalnya pada rumusan tujuan instruksional dalam ranah kognitif yang perilakunya memilih, sudah terkait pula 
ranah afektif (sikap hati). Melakukan perumusan tujuan berdasarkan ranah, selalu dipilih yang mana yang lebih dominan.

\section{B. Pembahasan}

\section{Taksonomi Bloom Ranah Kognitif}

Taksonomi Bloom mengklasifikasikan perilaku menjadi enam kategori, dari yang sederhana (mengetahui) sampai dengan yang lebih kompleks (mengevaluasi). Ranah kognitif terdiri atas (berturut-turut dari yang paling sederhana sampai yang paling kompleks), ialah:

\section{a. Pengetahuan (Knowledge ) / C - 1}

Pengetahuan dalam pengertian ini melibatkan proses mengingat kembali hal-hal yang spesifik dan universal, mengingat kembali metode dan proses, atau mengingat kembali pola, struktur atau setting. Pengetahuan dapat dibedakan menjadi tiga, yakni: (1) pengetahuan tentang hal-hal pokok; (2) pengetahuan tentang cara memperlakukan hal-hal pokok; dan (3) pengetahuan tentang hal yang umum dan abstraksi. Pengetahuan tentang hal-hal pokok yaitu mengingat kembali hal-hal yang spesifik, penekanannya pada simbol-simbol dari acuan yang konkret. Pengetahuan tentang hal-hal pokok dibagi menjadi dua yakni: (1) pengetahuan tentang terminologi; dan (2) pengetahuan mengenai fakta-fakta khusus. Pengetahuan tentang terminologi yaitu pengetahuan tentang acuan simbol yang diterima banyak orang, misalnya kata-kata umum beserta makna-maknanya yang lazim. Pengetahuan tentang fakta yang spesifik yaitu pengetahuan tentang tanggal, peristiwa, orang, tempat.

Pengetahuan tentang cara memperlakukan hal-hal pokok yaitu pengetahuan tentang cara-cara untuk mengorganisasi, mempelajari, menilai, dan mengkritik. Pengetahuan tentang cara memperlakukan hal-hal pokok dibagi menjadi lima yakni: (1) pengetahuan tentang konvensi; (2) pengetahuan tentang kecenderungan atau urutan; (3) pengetahuan tentang klasifikasi dan kategori; (4) pengetahuan tentang tolok ukur; dan (5) pengetahuan tentang metodologi. Pengetahuan tentang konvensi yaitu pengetahuan tentang cara-cara yang khas untuk mempresentasikan ide dan fenomena misalnya cara untuk mempresentasikan puisi, drama, dan makalah ilmiah. Pengetahuan tentang kecenderungan atau urutan yaitu pengetahuan tentang proses, arah, dan gerakan suatu fenomena dalam kaitannya dengan waktu misalnya pengetahuan tentang perkembangan kebudayaan Indonesia.

Pengetahuan tentang klasifikasi dan kategori yaitu pengetahuan tentang kelas, divisi, dan susunan yang dianggap fundamental bagi suatu bidang, tujuan, argumen, atau masalah. Pengetahuan tentang tolak ukur (kriteria) yaitu pengetahuan tentang kriteria-kriteria untuk menguji atau menilai fakta, prinsip, pendapat, dan perilaku. Pengetahuan tentang metodologi yaitu pengetahuan tentang metode-metode penelitian, teknik-teknik, dan prosedur-prosedur yang digunakan dalam suatu bidang dan untuk menyelidiki suatu masalah dan fenomena.

Pengetahuan tentang hal yang umum (universalitas) dan abstraksi dalam suatu bidang yaitu pengetahuan tentang skema-skema dan pola-pola pokok untuk mengorganisasi fenomena dan ide. Pengetahuan tentang hal yang umum dan 
abstraksi dibagi menjadi dua yakni: (1) pengetahuan tentang prinsip dan generalisasi; dan (2) pengetahuan tentang teori dan struktur. Pengetahuan tentang prinsip dan generalisasi yaitu pengetahuan tentang abstraksi-abstraksi tertentu yang merupakan rangkuman atas hasil pengamatan terhadap suatu fenomena. Pengetahuan tentang teori dan struktur yaitu pengetahuan tentang sekumpulan prinsip dan generalisasi beserta interelasi yang membentuk suatu pandangan yang jelas, utuh, dan sistematis mengenai sebuah fenomena, masalah, atau bidang yang kompleks.

\section{b. Pemahaman (Comprehension) / C - 2}

Pemahaman bersangkutan dengan inti dari sesuatu, ialah suatu bentuk pengertian atau pemahaman yang menyebabkan seseorang mengetahui apa yang sedang dikomunikasikan, dan dapat menggunakan bahan atau ide yang sedang dikomunikasikan itu tanpa harus menghubungkannya dengan bahan lain. Pemahaman dibedakan menjadi tiga, yakni: (1) penerjemahan (translasi) yaitu kemampuan untuk memahami suatu ide yang dinyatakan dengan cara lain dari pada pernyataan asli yang dikenal sebelumnya; (2) penafsiran (interpretasi) yaitu penjelasan atau rangkuman atas suatu komunikasi, misalnya menafsirkan berbagai data sosial yang direkam, diubah, atau disusun dalam bentuk lain seperti grafik, tabel, diagram; dan (3) ekstrapolasi yaitu meluaskan kecenderungan melampaui datanya untuk mengetahui implikasi, konsekuensi, akibat, pengaruh sesuai dengan kondisi suatu fenomena pada awalnya, misalnya membuat pernyataan-pernyataan yang eksplisit untuk menyikapi kesimpulan-kesimpulan dalam suatu karya sastra.

\section{c. Penerapan (Application) / C -3}

Di tingkat ini, seseorang memiliki kemampuan untuk menerapkan gagasan, prosedur, metode, rumus, teori, prinsip di dalam berbagai situasi. Sebagai contoh: agar teh dalam gelas cepat mendingin, maka tutup gelas harus dibuka (bidang fisika), orang perlu menyirami tanaman agar tidak layu (bidang biologi); dan jari yang terlukai harus diberi obat merah (bidang kesehatan).

\section{d. Analisis (Analysis) / C - 4}

Analisis diartikan sebagai pemecahan atau pemisahan suatu komunikasi (peristiwa, pengertian) menjadi unsur-unsur penyusunnya, sehingga ide (pengertian, konsep) itu relatif menjadi lebih jelas dan/atau hubungan antar ide-ide lebih eksplisit. Analisis merupakan memecahkan suatu isi komunikasi menjadi elemen-elemen sehingga hierarki ide-idenya menjadi jelas. Kategori analisis dibedakan menjadi tiga, yakni: (1) analisis elemen yaitu analisis elemen-elemen dari suatu komunikasi; (2) analisis hubungan yaitu analisis koneksi dan interaksi antara elemen-elemen dan bagian-bagian dari suatu komunikasi; dan (3) analisis prinsip pengorganisasian yaitu analisis susunan dan struktur yang membentuk suatu komunikasi.

\section{e. Sintesis (Synthesis) / C - 5}

Sintesis adalah memadukan elemen-elemen dan bagian-bagian untuk membentuk suatu kesatuan. Sintesis bersangkutan dengan penyusunan bagian- 
bagian atau unsur-unsur sehingga membentuk suatu keseluruhan atau kesatuan yang sebelumnya tidak tampak jelas. Kategori sintesis dibedakan menjadi tiga yakni: (1) penciptaan komunikasi yang unik, yaitu penciptaan komunikasi yang di dalamnya penulis atau pembicara berusaha mengemukakan ide, perasaan, dan pengalaman kepada orang lain; (2) penciptaan rencana yaitu penciptaan rencana kerja atau proposal operasi; dan (3) penciptaan rangkaian hubungan abstrak yaitu membuat rangkaian hubungan abstrak untuk mengklasifikasikan data tertentu.

\section{f. Evaluasi (Evaluation) / C - 6}

Evaluasi adalah menentukan nilai materi dan metode untuk tujuan tertentu. Evaluasi bersangkutan dengan penentuan secara kuantitatif atau kualitatif tentang nilai materi atau metode untuk sesuatu maksud dengan memenuhi tolok ukur tertentu. Kategori evaluasi dibedakan menjadi dua, yakni: (1) evaluasi berdasarkan bukti internal yaitu evaluasi terhadap ketetapan komunikasi berdasarkan logika, konsistensi, dan kriteria-kriteria internal lain misalnya, menunjukkan kesalahan-kesalahan logika dalam suatu argumen; dan (2) evaluasi berdasarkan bukti eksternal yaitu evaluasi terhadap materi berdasarkan kriteria yang ditetapkan atau diingat, misalnya membandingkan teori-teori, generalisasigeneralisasi, dan fakta-fakta pokok tentang kebudayaan tertentu.

Taksonomi Bloom ranah kognitif berturut-turut dari yang paling sederhana sampai yang paling kompleks diilustrasikan seperti pada Gambar 1.



\section{Gambar 1 Taksonomi Bloom Ranah Kognitif}

\section{Taksonomi Bloom Revisi}

Tingkatan-tingkatan dalam Taksonomi Bloom tersebut telah digunakan hampir setengah abad sebagai dasar untuk penyusunan tujuan-tujuan pendidikan, penyusunan tes, dan kurikulum di seluruh dunia. Kerangka pikir ini memudahkan guru memahami, menata, dan mengimplementasikan tujuan-tujuan pendidikan. Berdasarkan hal tersebut Taksonomi Bloom menjadi sesuatu yang penting dan mempunyai pengaruh yang luas dalam waktu yang lama. Namun pada tahun 2001 terbit sebuah buku A Taxonomy for Learning, Teaching, and Assesing: A Revision of Bloom's Taxonomy of Educatioanl Objectives yang disusun oleh Lorin W. Anderson dan David R. Krathwohl.

Mungkin banyak orang bertanya mengapa buku hebat Taksonomi Bloom harus direvisi? Ada beberapa alasan mengapa Handbook Taksonomi Bloom perlu direvisi, yakni: pertama, terdapat kebutuhan untuk mengarahkan kembali fokus 
para pendidik pada handbook, bukan sekedar sebagai dokumen sejarah, melainkan juga sebagai karya yang dalam banyak hal telah "mendahului" zamannya (Rohwer dan Sloane, 1994). Hal tersebut mempunyai arti banyak gagasan dalam handbook Taksonomi Bloom yang dibutuhkan oleh pendidik masa kini karena pendidikan masih terkait dengan masalah-masalah desain pendidikan, penerapan program yang tepat, kurikulum standar, dan asesmen autentik.

Alasan kedua adalah adanya kebutuhan untuk memadukan pengetahuanpengetahuan dan pemikiran-pemikiran baru dalam sebuah kerangka kategorisasi tujuan pendidikan. Masyarakat dunia telah banyak berubah sejak tahun 1956, dan perubahan-perubahan ini mempengaruhi cara berpikir dan praktik pendidikan. Kemajuan dalam ilmu pengetahuan ini mendukung keharusan untuk merevisi handbook Taksonomi Bloom. Alasan yang ketiga adalah taksonomi merupakan sebuah kerangka berpikir khusus yang menjadi dasar untuk mengklasifikasikan tujuan-tujuan pendidikan. Sebuah rumusan tujuan pendidikan seharusnya berisikan satu kata kerja dan satu kata benda. Kata kerjanya umumnya mendeskripsikan proses kognitif yang diharapkan dan kata bendanya mendeskripsikan pengetahuan yang diharapkan dikuasai oleh siswa. Taksonomi Bloom hanya mempunyai satu dimensi yaitu hanya kata benda. Menurut Tyler (1994) rumusan tujuan yang paling bermanfaat adalah rumusan yang menunjukkan jenis perilaku yang akan diajarkan kepada siswa dan isi pembelajaran yang membuat siswa menunjukkan perilaku itu. Berdasarkan hal tersebut rumusan tujuan pendidikan harus memuat dua dimensi yaitu dimensi pertama untuk menunjukkan jenis perilaku siswa dengan menggunakan kata kerja dan dimensi kedua untuk menunjukkan isi pembelajaran dengan menggunakan kata benda.

Alasan keempat yaitu proporsi yang tidak sebanding dalam penggunaan taksonomi pendidikan untuk perencanaan kurikulum dan pembelajaran dengan penggunaan taksonomi pendidikan untuk asesmen. Pada taksonomi Bloom lebih memfokuskan penggunakan taksonomi pada asesmen. Alasan yang kelima adalah pada kerangka pikir taksonomi karya Benjamin Bloom lebih menekankan enam kategorinya (pengetahuan, pemahaman, penerapan, analisis, sintesis, dan evaluasi) daripada sub-subkategorinya. Taksonomi Bloom menjabarkan enam kategori tersebut secara mendetail, namun kurang menjabarkan pada subkategorinya sehingga sebagian orang akan lupa dengan sub-subkategori taksonomi Bloom.

Alasan keenam adalah ketidakseimbangan proporsi subkategori dari taksonomi Bloom. Kategori pengetahuan dan komprehensi memiliki banyak subkategori namun empat kategori lainnya hanya memiliki sedikit subkategori. Alasan ketujuh adalah taksonomi Bloom versi aslinya lebih ditujukan untuk dosen-dosen, padahal dalam dunia pendidikan tidak hanya dosen yang berperan untuk merencanakan kurikulum, pembelajaran, dan penilaian. Oleh sebab itu dibutuhkan sebuah revisi taksonomi yang dapat lebih luas menjangkau seluruh pelaku dalam dunia pendidikan. Perubahan dari kerangka pikir asli ke revisinya diilustrasikan pada Gambar 2.

Berdasarkan Gambar 2 dapat diketahui perubahan taksonomi dari kata benda (dalam taksonomi Bloom) menjadi kata kerja (dalam taksonomi revisi). Perubahan ini dibuat agar sesuai dengan tujuan-tujuan pendidikan. Tujuan-tujuan 
pendidikan mengindikasikan bahwa siswa akan dapat melakukan sesuatu (kata kerja) dengan sesuatu (kata benda). Kategori pengetahuan dalam taksonomi Bloom berubah menjadi mengingat. Bentuk kata kerja mengingat mendeskripsikan tindakan yang tersirat dalam kategori pengetahuan aslinya; tindakan pertama yang dilakukan oleh siswa dalam belajar pengetahuan adalah mengingatnya. Kategori pemahaman menjadi memahami. Pemahaman merupakan tingkat memahami yang paling rendah. Pemahaman terbatas pada hanya memahami tentang apa yang sedang dikomunikasikan tanpa menghubungkannya dengan materi lain. Perubahan dari pemahaman menjadi memahami karena dalam pemilihan nama-nama kategori, mempertimbangkan keluasan pemakaian istilah tersebut oleh banyak guru.

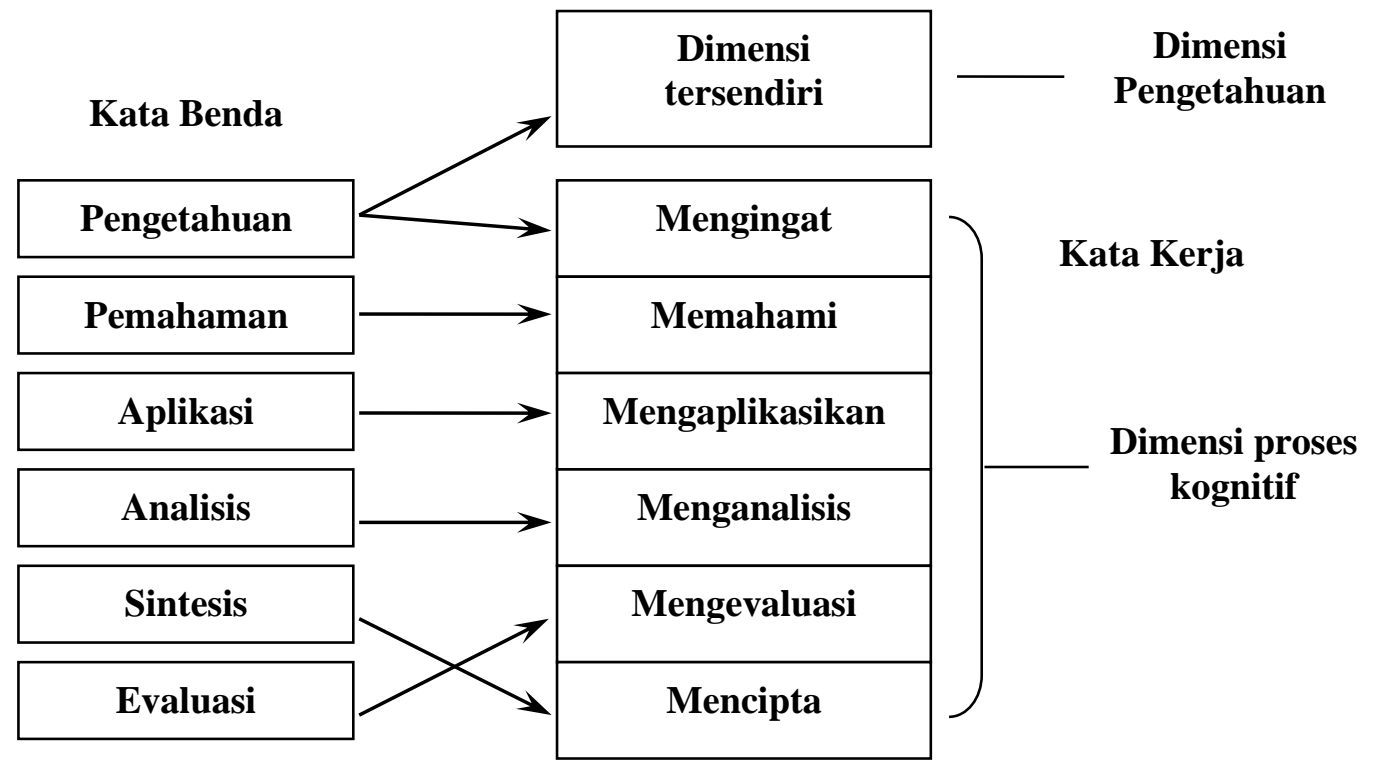

Gambar 2 Perubahan dari Kerangka Pikir Asli ke Revisi (Anderson dan Krathwohl, 2001:268)

Kategori aplikasi menjadi mengaplikasikan. Dalam kategori ini hanya terjadi perubahan dari kata benda menjadi kata kerja. Kategori analisis menjadi menganalisis. Dalam kategori ini hanya terjadi perubahan dari kata benda menjadi kata kerja. Kategori sintesis menjadi mencipta. Mencipta melibatkan proses menyusun elemen-elemen menjadi sebuah kesatuan yang koheren dan fungsional yang akhirnya dapat menghasilkan sebuah produk baru yang belum pernah ada sebelumnya. Sintesis hanya terbatas pada memadukan elemen-elemen dan bagian-bagian untuk membentuk satu kesatuan dengan melibatkan proses mengolah potongan-potongan, bagian-bagian, elemen-elemen dan mengatur serta memadukan sedemikian rupa sehingga membentuk sebuah pola atau struktur yang sebelumnya tidak jelas. Kategori evaluasi menjadi mengevaluasi. Dalam kategori ini hanya terjadi perubahan dari kata benda menjadi kata kerja.

Perubahan pengetahuan dalam taksonomi Bloom menjadi dimensi tersendiri yaitu dimensi pengetahuan dalam taksonomi revisi. Pengetahuan tetap dipertahankan dalam taksonomi revisi namun berubah menjadi dimensi tersendiri 
karena diasumsikan bahwa setiap kategori-kategori dalam taksonomi membutuhkan pengetahuan sebagai apa yang harus dipelajari oleh siswa. Taksonomi revisi memiliki dua dimensi yaitu dimensi pengetahuan dan dimensi kognitif proses. Interelasi antara proses kognitif dan pengetahuan disebut dengan Tabel Taksonomi (Tabel 2, Gambar 3).

Konsep-konsep pembelajaran yang berkembang terfokus pada prosesproses aktif, kognitif dan konstruktif dalam pembelajaran yang bermakna. Pembelajar diasumsikan sebagai pelaku yang aktif dalam aktivitas belajar; mereka memilih informasi yang akan mereka pelajari, dan mengonstruksi makna berdasarkan informasi. Ini merupakan perubahan dari pandangan pasif tentang pembelajaran ke pandangan kognitif dan konstruktif yang menekankan apa yang siswa ketahui (pengetahuan) dan bagaimana mereka berpikir (proses kognitif) tentang apa yang mereka ketahui ketika aktif dalam pembelajaran. Dimensi proses kognitif berisikan enam kategori yaitu: mengingat, memahami, mengaplikasikan, menganalisis, mengevaluasi, dan mencipta. Dimensi pengetahuan berisikan empat kategori yaitu faktual, konseptual, prosedural, dan metakognitif.

Urutan sintesis dan evaluasi ditukar. Taksonomi revisi mengubah urutan dua kategori proses kognitif dengan menempatkan mencipta sebagai kategori yang paling kompleks. Kategori-kategori pada taksonomi Bloom disusun menjadi sebuah hierarki kumulatif yang berarti penguasaan kategori yang lebih kompleks mensyaratkan penguasaan semua kategori di bawahnya yang kurang kompleks. Penelitian-penelitian kemudian memberikan bukti-bukti empiris bahwa hierarki kumulatif hanya berlaku pada tiga kategori tengahnya yakni pemahaman, aplikasi, dan analisis, tetapi tidak pada dua kategori terakhir (sintesis dan evaluasi). Penelitian membuktikan sintesis merupakan kategori yang lebih kompleks daripada evaluasi.

Sehingga Taksonomi Bloom ranah kognitif yang telah direvisi Anderson dan Krathwohl (2001:66-88) yakni: mengingat (remember), memahami/mengerti (understand), menerapkan (apply), menganalisis (analyze), mengevaluasi (evaluate), dan menciptakan (create).

\section{a. Mengingat (Remember)}

Mengingat merupakan usaha mendapatkan kembali pengetahuan dari memori atau ingatan yang telah lampau, baik yang baru saja didapatkan maupun yang sudah lama didapatkan. Mengingat merupakan dimensi yang berperan penting dalam proses pembelajaran yang bermakna (meaningful learning) dan pemecahan masalah (problem solving). Kemampuan ini dimanfaatkan untuk menyelesaikan berbagai permasalahan yang jauh lebih kompleks. Mengingat meliputi mengenali (recognition) dan memanggil kembali (recalling). Mengenali berkaitan dengan mengetahui pengetahuan masa lampau yang berkaitan dengan hal-hal yang konkret, misalnya tanggal lahir, alamat rumah, dan usia, sedangkan memanggil kembali (recalling) adalah proses kognitif yang membutuhkan pengetahuan masa lampau secara cepat dan tepat.

\section{b. Memahami/mengerti (Understand)}

Memahami/mengerti berkaitan dengan membangun sebuah pengertian dari berbagai sumber seperti pesan, bacaan dan komunikasi. Memahami/mengerti 
berkaitan dengan aktivitas mengklasifikasikan (classification) dan membandingkan (comparing). Mengklasifikasikan akan muncul ketika seorang siswa berusaha mengenali pengetahuan yang merupakan anggota dari kategori pengetahuan tertentu.

Mengklasifikasikan berawal dari suatu contoh atau informasi yang spesifik kemudian ditemukan konsep dan prinsip umumnya. Membandingkan merujuk pada identifikasi persamaan dan perbedaan dari dua atau lebih obyek, kejadian, ide, permasalahan, atau situasi. Membandingkan berkaitan dengan proses kognitif menemukan satu persatu ciri-ciri dari obyek yang diperbandingkan.

\section{c. Menerapkan (Apply)}

Menerapkan menunjuk pada proses kognitif memanfaatkan atau mempergunakan suatu prosedur untuk melaksanakan percobaan atau menyelesaikan permasalahan. Menerapkan berkaitan dengan dimensi pengetahuan prosedural (procedural knowledge). Menerapkan meliputi kegiatan menjalankan prosedur (executing) dan mengimplementasikan (implementing).

Menjalankan prosedur merupakan proses kognitif siswa dalam menyelesaikan masalah dan melaksanakan percobaan di mana siswa sudah mengetahui informasi tersebut dan mampu menetapkan dengan pasti prosedur apa saja yang harus dilakukan. Jika siswa tidak mengetahui prosedur yang harus dilaksanakan dalam menyelesaikan permasalahan maka siswa diperbolehkan melakukan modifikasi dari prosedur baku yang sudah ditetapkan.

Mengimplementasikan muncul apabila siswa memilih dan menggunakan prosedur untuk hal-hal yang belum diketahui atau masih asing. Karena siswa masih merasa asing dengan hal ini maka siswa perlu mengenali dan memahami permasalahan terlebih dahulu kemudian baru menetapkan prosedur yang tepat untuk menyelesaikan masalah. Mengimplementasikan berkaitan erat dengan dimensi proses kognitif yang lain yaitu mengerti dan menciptakan.

Menerapkan merupakan proses yang kontinu, dimulai dari siswa menyelesaikan suatu permasalahan menggunakan prosedur baku/standar yang sudah diketahui. Kegiatan ini berjalan teratur sehingga siswa benar-benar mampu melaksanakan prosedur ini dengan mudah, kemudian berlanjut pada munculnya permasalahan-permasalahan baru yang asing bagi siswa, sehingga siswa dituntut untuk mengenal dengan baik permasalahan tersebut dan memilih prosedur yang tepat untuk menyelesaikan permasalahan.

\section{d. Menganalisis (Analyze)}

Menganalisis merupakan memecahkan suatu permasalahan dengan memisahkan tiap-tiap bagian dari permasalahan dan mencari keterkaitan dari tiaptiap bagian tersebut dan mencari tahu bagaimana keterkaitan tersebut dapat menimbulkan permasalahan. Kemampuan menganalisis merupakan jenis kemampuan yang banyak dituntut dari kegiatan pembelajaran di sekolah-sekolah. Berbagai mata pelajaran menuntut siswa memiliki kemampuan menganalisis dengan baik. Tuntutan terhadap siswa untuk memiliki kemampuan menganalisis sering kali cenderung lebih penting daripada dimensi proses kognitif yang lain seperti mengevaluasi dan menciptakan. Kegiatan pembelajaran sebagian besar 
mengarahkan siswa untuk mampu membedakan fakta dan pendapat, menghasilkan kesimpulan dari suatu informasi pendukung.

Menganalisis berkaitan dengan proses kognitif memberi atribut (attributeing) dan mengorganisasikan (organizing). Memberi atribut akan muncul apabila siswa menemukan permasalahan dan kemudian memerlukan kegiatan membangun ulang hal yang menjadi permasalahan. Kegiatan mengarahkan siswa pada informasi-informasi asal mula dan alasan suatu hal ditemukan dan diciptakan. Mengorganisasikan menunjukkan identifikasi unsur-unsur hasil komunikasi atau situasi dan mencoba mengenali bagaimana unsur-unsur ini dapat menghasilkan hubungan yang baik. Mengorganisasikan memungkinkan siswa membangun hubungan yang sistematis dan koheren dari potongan-potongan informasi yang diberikan. Hal pertama yang harus dilakukan oleh siswa adalah mengidentifikasi unsur yang paling penting dan relevan dengan permasalahan, kemudian melanjutkan dengan membangun hubungan yang sesuai dari informasi yang telah diberikan.

\section{e. Mengevaluasi (Evaluate)}

Evaluasi berkaitan dengan proses kognitif memberikan penilaian berdasarkan kriteria dan standar yang sudah ada. Kriteria yang biasanya digunakan adalah kualitas, efektivitas, efisiensi, dan konsistensi. Kriteria atau standar ini dapat pula ditentukan sendiri oleh siswa. Standar ini dapat berupa kuantitatif maupun kualitatif serta dapat ditentukan sendiri oleh siswa. Perlu diketahui bahwa tidak semua kegiatan penilaian merupakan dimensi mengevaluasi, namun hampir semua dimensi proses kognitif memerlukan penilaian. Perbedaan antara penilaian yang dilakukan siswa dengan penilaian yang merupakan evaluasi adalah pada standar dan kriteria yang dibuat oleh siswa. Jika standar atau kriteria yang dibuat mengarah pada keefektifan hasil yang didapatkan dibandingkan dengan perencanaan dan keefektifan prosedur yang digunakan maka apa yang dilakukan siswa merupakan kegiatan evaluasi.

Evaluasi meliputi mengecek (checking) dan mengkritisi (critiquing). Mengecek mengarah pada kegiatan pengujian hal-hal yang tidak konsisten atau kegagalan dari suatu operasi atau produk. Jika dikaitkan dengan proses berpikir merencanakan dan mengimplementasikan maka mengecek akan mengarah pada penetapan sejauh mana suatu rencana berjalan dengan baik. Mengkritisi mengarah pada penilaian suatu produk atau operasi berdasarkan pada kriteria dan standar eksternal. Mengkritisi berkaitan erat dengan berpikir kritis. Siswa melakukan penilaian dengan melihat sisi negatif dan positif dari suatu hal, kemudian melakukan penilaian menggunakan standar ini.

\section{f. Menciptakan (Create)}

Menciptakan mengarah pada proses kognitif meletakkan unsur-unsur secara bersama-sama untuk membentuk kesatuan yang koheren dan mengarahkan siswa untuk menghasilkan suatu produk baru dengan mengorganisasikan beberapa unsur menjadi bentuk atau pola yang berbeda dari sebelumnya. Menciptakan sangat berkaitan erat dengan pengalaman belajar siswa pada pertemuan sebelumnya. Meskipun menciptakan mengarah pada proses berpikir kreatif, 
namun tidak secara total berpengaruh pada kemampuan siswa untuk menciptakan. Menciptakan di sini mengarahkan siswa untuk dapat melaksanakan dan menghasilkan karya yang dapat dibuat oleh semua siswa. Perbedaan menciptakan ini dengan dimensi berpikir kognitif lainnya adalah pada dimensi yang lain seperti mengerti, menerapkan, dan menganalisis siswa bekerja dengan informasi yang sudah dikenal sebelumnya, sedangkan pada menciptakan siswa bekerja dan menghasilkan sesuatu yang baru.

Menciptakan meliputi menggeneralisasikan (generating) dan memproduksi (producing). Menggeneralisasikan merupakan kegiatan merepresentasikan permasalahan dan penemuan alternatif hipotesis yang diperlukan. Menggeneralisasikan ini berkaitan dengan berpikir divergen yang merupakan inti dari berpikir kreatif. Memproduksi mengarah pada perencanaan untuk menyelesaikan permasalahan yang diberikan. Memproduksi berkaitan erat dengan dimensi pengetahuan yang lain yaitu pengetahuan faktual, pengetahuan konseptual, pengetahuan prosedural, dan pengetahuan metakognisi. Taksonomi Anderson dan Krathwohl (2001:66-88) disajikan pada Tabel 1.

Tabel 1 Taksonomi Anderson dan Krathwohl

\begin{tabular}{|c|c|c|}
\hline Tingkatan & Berpikir Tingkat Tinggi & $\begin{array}{c}\text { Komunikasi } \\
\text { (communication } \\
\text { spectrum) }\end{array}$ \\
\hline Menciptakan (Creating) & $\begin{array}{l}\text { Menggeneralisasikan (generating), } \\
\text { merancang (designing), } \\
\text { memproduksi (producing), } \\
\text { merencanakan kembali (devising) }\end{array}$ & $\begin{array}{l}\text { Negosiasi (negotiating), } \\
\text { memoderatori } \\
\text { (moderating), kolaborasi } \\
\text { (collaborating) }\end{array}$ \\
\hline $\begin{array}{l}\text { Mengevaluasi } \\
\text { (Evaluating) }\end{array}$ & $\begin{array}{l}\text { Mengecek (checking), mengkritisi } \\
\text { (critiquing), hipotesa } \\
\text { (hypothesising), eksperimen } \\
\text { (experimenting) }\end{array}$ & $\begin{array}{l}\text { Bertemu dengan } \\
\text { jaringan/mendiskusikan } \\
\text { (net meeting), berkomentar } \\
\text { (commenting), berdebat } \\
\text { (debating) }\end{array}$ \\
\hline Menganalisis (Analyzing) & $\begin{array}{l}\text { Memberi atribut (attributeing), } \\
\text { mengorganisasikan (organizing), } \\
\text { mengintegrasikan (integrating), } \\
\text { mensahihkan (validating) }\end{array}$ & $\begin{array}{l}\text { Menanyakan } \\
\text { (Questioning), meninjau } \\
\text { ulang (reviewing) }\end{array}$ \\
\hline Menerapkan (Applying) & $\begin{array}{l}\text { Menjalankan prosedur (executing), } \\
\text { mengimplementasikan } \\
\text { (implementing), menyebarkan } \\
\text { (sharing), }\end{array}$ & $\begin{array}{l}\text { Posting, blogging, } \\
\text { menjawab (replying) }\end{array}$ \\
\hline $\begin{array}{l}\text { Memahami/mengerti } \\
\text { (Understanding) }\end{array}$ & $\begin{array}{l}\text { Mengklasifikasikan (classification), } \\
\text { membandingkan (comparing), } \\
\text { menginterpretasikan (interpreting), } \\
\text { berpendapat (inferring) }\end{array}$ & $\begin{array}{l}\text { Bercakap (chatting), } \\
\text { menyumbang } \\
\text { (contributing), networking, }\end{array}$ \\
\hline \multirow[t]{2}{*}{$\begin{array}{l}\text { Mengingat } \\
\text { (Remembering) }\end{array}$} & $\begin{array}{l}\text { Mengenali (recognition), memanggil } \\
\text { kembali (recalling), } \\
\text { mendeskripsikan (describing), } \\
\text { mengidentifikasi (identifying) }\end{array}$ & $\begin{array}{l}\text { Menulis teks (texting), } \\
\text { mengirim pesan singkat } \\
\text { (instant messaging), } \\
\text { berbicara (twittering) }\end{array}$ \\
\hline & Berpikir Tingkat Rendah & \\
\hline
\end{tabular}




\section{Dimensi Pengetahuan Taksonomi Revisi}

Dimensi pengetahuan (Tabel 2) merupakan dimensi tersendiri dalam Taksonomi Bloom revisi. Dalam dimensi ini akan dipaparkan empat jenis kategori pengetahuan. Tiga jenis pertama dalam taksonomi revisi ini mencakup semua jenis pengetahuan yang terdapat dalam taksonomi Bloom, namun mengganti sebagian nama jenisnya dan mengubah sebagian subjenisnya ke dalam kategorikategori yang lebih umum. Sementara kategori keempat, yaitu pengetahuan metakognitif dan subjenisnya semuanya baru.

Tabel 2 The Knowledge Dimension-Major Types and Subtypes

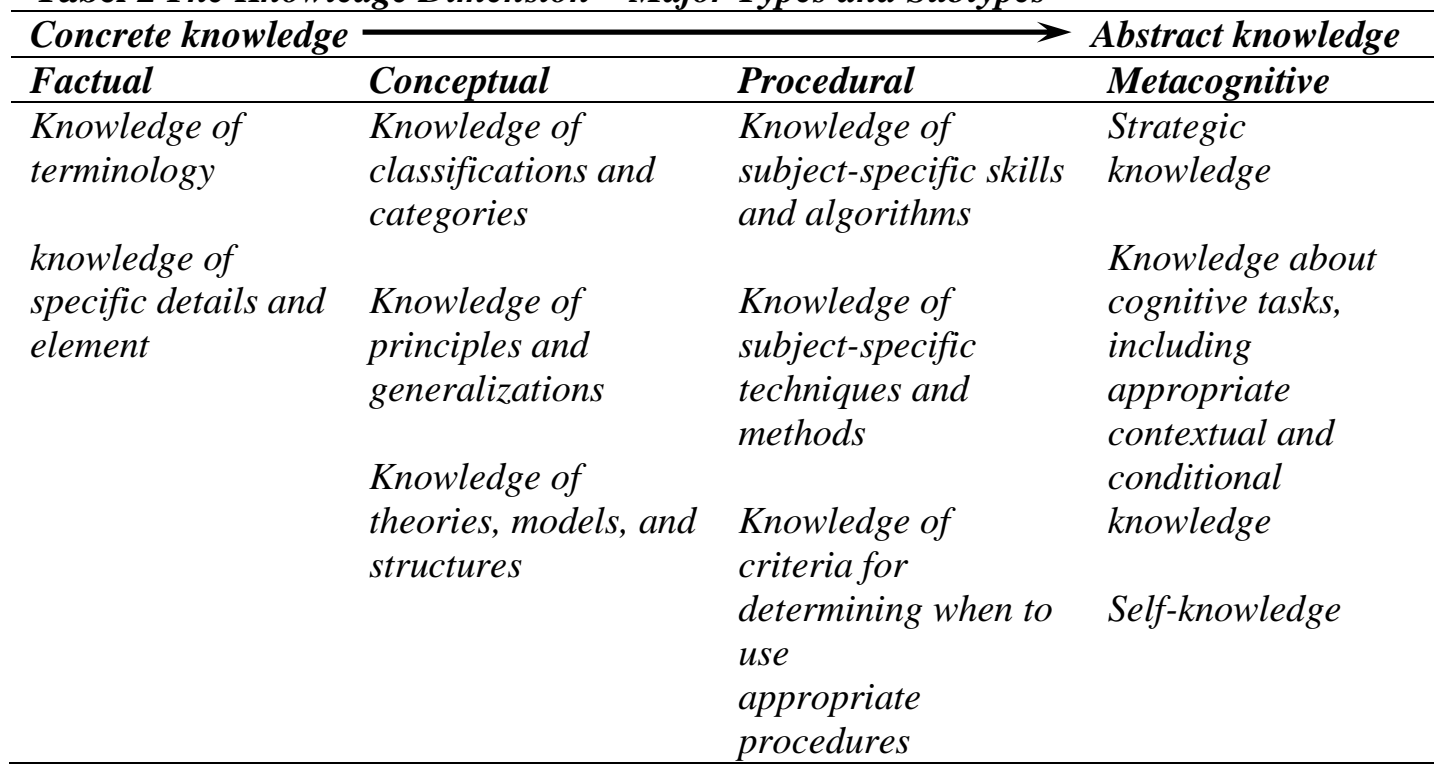

\section{a. Pengetahuan Faktual}

Pengetahuan faktual meliputi elemen-elemen dasar yang digunakan oleh para pakar dalam menjelaskan, memahami, dan secara sistematis menata disiplin ilmu mereka. Pengetahuan faktual berisikan elemen-elemen dasar yang harus diketahui siswa jika mereka akan mempelajari suatu disiplin ilmu atau menyelesaikan masalah dalam disiplin ilmu tersebut. Pengetahuan faktual terbagi menjadi dua subjenis yaitu: (1) pengetahuan tentang terminologi; dan (2) pengetahuan tentang detail-detail dan elemen-elemen yang spesifik. Pengetahuan tentang terminologi melingkupi pengetahuan tentang label dan simbol verbal dan nonverbal (kata, angka, tanda, gambar). Setiap materi kajian mempunyai banyak label dan simbol, baik verbal maupun nonverbal, yang merujuk pada maknamakna tertentu. Label dan simbol ini merupakan bahasa dasar dalam suatu disiplin ilmu. Contoh-contoh penggunaan pengetahuan terminologi antara lain pengetahuan tentang alfabet, pengetahuan tentang angka-angka Romawi, pengetahuan tentang kosakata dalam bahasa Indonesia, dan pengetahuan tentang simbol-simbol pada peta.

Pengetahuan tentang detail-detail dan elemen-elemen yang spesifik merupakan pengetahuan tentang peristiwa, lokasi, orang, tanggal, sumber 
informasi, dan semacamnya. Pengetahuan ini meliputi semua informasi yang mendetail dan spesifik, seperti tanggal terjadinya sebuah peristiwa. Fakta-fakta yang spesifik adalah fakta-fakta yang dapat disendirikan sebagai elemen-elemen yang terpisah dan berdiri sendiri. Setiap bidang kajian mengandung peristiwa, lokasi, orang, tanggal, dan detail-detail lain yang mempresentasikan pengetahuan penting tentang bidang itu. Contoh pengetahuan tentang detail-detail dan elemenelemen yang spesifik antara lain pengetahuan tentang nama orang, tempat, dan peristiwa dalam proklamasi, pengetahuan tentang produk utama dan produk ekspor Indonesia.

\section{b. Pengetahuan Konseptual}

Pengetahuan konseptual mencakup pengetahuan tentang kategori, klasifikasi, dan hubungan antara dua atau lebih kategori pengetahuan yang lebih kompleks dan tertata. Pengetahuan konseptual meliputi skema, model, mental, dan teori yang mempresentasikan pengetahuan manusia tentang bagaimana suatu materi kajian ditata dan distrukturkan, bagaimana bagian-bagian informasi saling berkaitan secara sistematis, dan bagaimana bagian-bagian ini berfungsi bersama. Pengetahuan konseptual terdiri dari tiga subjenis yaitu: (1) pengetahuan tentang klasifikasi dan kategori; (2) pengetahuan tentang prinsip dan generalisasi; dan (3) pengetahuan tentang teori, model, dan struktur. Klasifikasi dan kategori merupakan landasan bagi prinsip dan generalisasi. Prinsip dan generalisasi menjadi dasar bagi teori, model, dan struktur.

Pengetahuan tentang klasifikasi dan kategori meliputi kelas, kategori, divisi, dan susunan yang spesifik dalam disiplin-disiplin ilmu. Setiap disiplin ilmu memiliki serangkaian kategori yang digunakan untuk menemukan dan mengkaji elemen-elemen baru. Klasifikasi dan kategori menciptakan hubungan-hubungan antara elemen-elemen. Pengetahuan tentang klasifikasi dan kategori dapat dicontohkan misalnya: ketika peserta didik menganalisis sebuah cerita dengan kategori pokok berupa alur, tokoh, dan setting. Dalam hal alur sebagai pengetahuan tentang kategori adalah apa yang menjadikan alur tersebut disebut dengan alur yang berarti alur sebagai kategori adalah ciri-ciri yang dimiliki oleh semua alur.

Prinsip dan generalisasi dibentuk oleh klasifikasi dan kategori. Prinsip dan generalisasi merupakan bagian yang dominan dalam sebuah disiplin ilmu dan digunakan untuk mengkaji masalah-masalah dalam disiplin ilmu tersebut. Prinsip dan generalisasi merangkum banyak fakta dan peristiwa yang spesifik, mendeskripsikan proses dan interelasi di antara detail-detail fakta dan peristiwa, dan menggambarkan proses dan interelasi di antara klasifikasi dan kategori. Contoh tentang pengetahuan tentang prinsip dan generalisasi antara lain pengetahuan tentang generalisasi-generalisasi dalam kebudayaan-kebudayaan suku Jawa, pengetahuan tentang hukum-hukum geometri dasar.

Pengetahuan tentang teori, model, dan struktur mencakup pengetahuan tentang berbagai paradigma, epistemologi, teori, model yang digunakan dalam disiplin-disiplin ilmu untuk mendeskripsikan, memahami, menjelaskan, dan memprediksi fenomena. Contoh pengetahuan tentang teori, model, dan struktur antara lain pengetahuan tentang interelasi antara prinsip-prinsip dalam 
penjumlahan sebagai dasar bagi teori-teori matematika, pengetahuan tentang struktur inti pemerintahan kota setempat.

\section{c. Pengetahuan Prosedural}

Pengetahuan prosedural adalah "pengetahuan tentang cara" melakukan sesuatu. Pengetahuan ini mencakup pengetahuan tentang keterampilan, algoritma, teknik, dan metode, yang semuanya disebut dengan prosedur (Alexander, dkk., 1991; Anderson, 1983; deJong dan Ferguson-Hessler, 1996; Dochy dan Alexander, 1995). Pengetahuan prosedural berkaitan dengan pertanyaan "bagaimana". Pengetahuan prosedural ini terbagi menjadi tiga subjenis yaitu: (1) pengetahuan tentang keterampilan dalam bidang tertentu dan algoritma; (2) pengetahuan tentang teknik dan metode dalam bidang tertentu; dan (3) pengetahuan tentang kriteria untuk menentukan kapan harus menggunakan prosedur yang tepat.

Pengetahuan tentang keterampilan dalam bidang tertentu dan algoritma, pengetahuan ini misalnya cara menjumlahkan 2 dan 2 (algoritma) adalah pengetahuan prosedural; jawabannya 4 merupakan pengetahuan faktual. Pengetahuan tentang teknik dan metode dalam bidang tertentu, pengetahuan ini adalah bagaimana cara berpikir dan menyelesaikan masalah-masalah, bukan hasil penyelesaian masalah atau hasil pemikirannya. Pengetahuan tentang kriteria untuk menentukan kapan harus menggunakan prosedur yang tepat, pengetahuan ini dapat kita contohkan antara lain pengetahuan tentang kriteria untuk menentukan jenis esai apa yang harus ditulis (misalnya: eksposisi, persuasi), pengetahuan tentang kriteria untuk menentukan metode apa dalam menyelesaikan persamaanpersamaan aljabar.

\section{d. Pengetahuan Metakognitif}

Pengetahuan metakognitif merupakan dimensi baru dalam taksonomi revisi. Pencantuman pengetahuan metakognitif dalam kategori dimensi pengetahuan dilandasi oleh hasil penelitian-penelitian terbaru tentang peran penting pengetahuan siswa mengenai kognisi mereka sendiri dan kontrol mereka atas kognisi itu dalam aktivitas belajar (Bransford, dkk.,1999; Sternberg, 1985; Zimmerman dan Schunk, 1998). Salah satu ciri belajar dan penelitian tentang pembelajaran yang berkembang adalah menekankan pada metode untuk membuat siswa semakin menyadari dan bertanggung jawab atas pengetahuan dan pemikiran mereka sendiri. Pengetahuan metakognitif terbagi menjadi tiga subjenis yaitu: (1) pengetahuan strategis; (2) pengetahuan tentang tugas-tugas kognitif yang meliputi pengetahuan kontekstual dan kondisional; dan (3) pengetahuan diri.

Pengetahuan strategis adalah pengetahuan tentang strategi-strategi belajar dan berpikir serta pemecahan masalah. Subjenis pengetahuan ini mencakup pengetahuan tentang berbagai strategi yang dapat digunakan siswa untuk menghafal materi pelajaran, mencari makna teks, atau memahami apa yang mereka dengar dari pelajaran di kelas atau yang dibaca dalam buku dan bahan ajar lain. Strategi-strategi belajar ini dikelompokkan menjadi tiga kategori yaitu pengulangan, elaborasi, dan organisasi. 
Strategi pengulangan berupa mengulang-ulang kata-kata atau istilah-istilah untuk memberikan ingatan pada mereka. Strategi elaborasi menggunakan berbagai teknik, yakni: merangkum, memparafrase, dan memilih gagasan pokok dalam teks. Strategi pengorganisasian adalah membuat garis besar materi pelajaran, membuat pemetaan konsep, dan membuat catatan. Pengetahuan tentang tugastugas kognitif yang meliputi pengetahuan kontekstual dan kondisional. Menurut Flavell (1979) pengetahuan metakognitif mencakup pengetahuan bahwa berbagai tugas kognitif itu sulit dan memerlukan sistem kognitif dan strategi-strategi kognitif. Selain mengetahui strategi belajar dan berpikir, juga memerlukan pengetahuan kondisional yaitu siswa harus tahu kapan dan mengapa menggunakan strategi-strategi tersebut dengan tepat (Paris, dkk., 1983).

Flavel (1979) mengemukakan bahwa selain pengetahuan tentang beragam strategi dan tugas kognitif, pengetahuan diri juga merupakan komponen yang penting dalam metakognitif. Pengetahuan diri mencakup pengetahuan tentang kekuatan, kelemahan, minat, bakat, motivasi dalam kaitannya dengan kognisi dan belajar. Gambar 3 menampilkan kombinasi cognitive process dan knowledge dimensions.

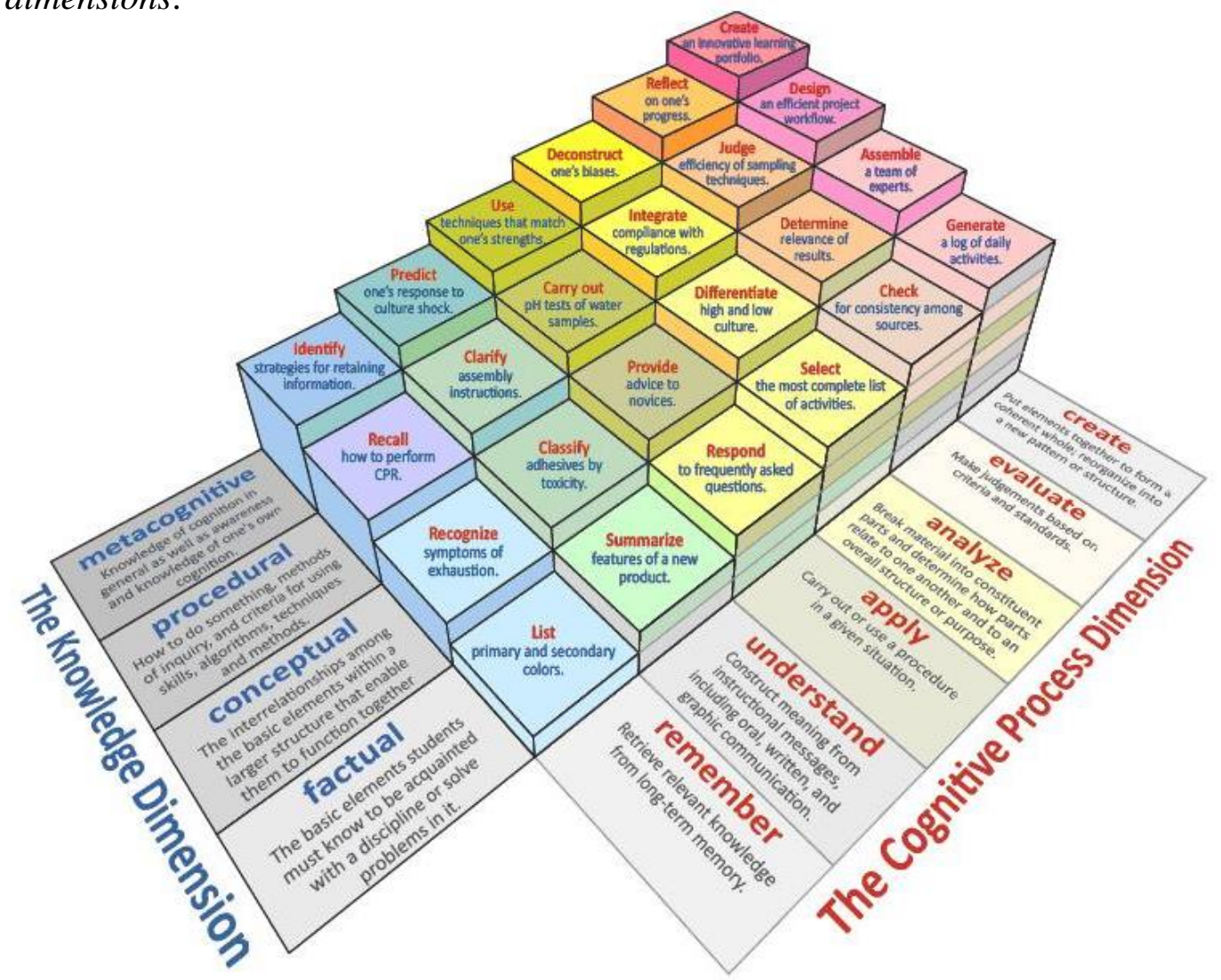

Gambar 3 Combinations of the Cognitive Process and Knowledge Dimensions (Heer, 2012)

Dimensi proses kognitif dalam taksonomi revisi terbagi menjadi 6 kategori yaitu: mengingat, memahami, mengaplikasikan, menganalisis, mengevaluasi, dan mencipta. Kategori-kategori tersebut akan dijelaskan dalam Tabel 3. 
Tabel 3 Kategori Taksonomi Anderson dan Kratwohl

\begin{tabular}{|c|c|c|}
\hline $\begin{array}{c}\text { Kategori dan } \\
\text { Proses Kognitif }\end{array}$ & Nama-Nama Lain & Definisi dan Contoh \\
\hline \multicolumn{3}{|c|}{ 1. Mengingat - Mengambil pengetahuan dari memori jangka panjang } \\
\hline 1.1 Mengenali & Mengidentifikasi & $\begin{array}{l}\text { Menempatkan pengetahuan dalam memori } \\
\text { jangka panjang yang sesuai dengan } \\
\text { pengetahuan tersebut (misalnya, mengenali } \\
\text { tanggal terjadinya peristiwa penting dalam } \\
\text { sejarah Indonesia) }\end{array}$ \\
\hline $\begin{array}{l}\text { 1.2Mengingat } \\
\text { kembali }\end{array}$ & Mengambil & $\begin{array}{l}\text { Mengambil pengetahuan yang relevan dari } \\
\text { memori jangka panjang (misalnya mengingat } \\
\text { kembali tanggal peristiwa-peristiwa penting } \\
\text { dalam sejarah Indonesia) }\end{array}$ \\
\hline \multicolumn{3}{|c|}{$\begin{array}{l}\text { 2. Memahami - Mengkonstruksi makna dari materi pembelajaran, termasuk apa yang } \\
\text { diucapkan, ditulis, dan digambar oleh guru }\end{array}$} \\
\hline 2.1 Menafsirkan & $\begin{array}{l}\text { Mengklarifikasikan } \\
\text { Memparafrasekan } \\
\text { Mempresentasi } \\
\text { Menerjemahkan }\end{array}$ & $\begin{array}{l}\text { Mengubah satu bentuk gambaran (misalnya } \\
\text { angka) jadi bentuk lain (misalnya kata-kata), } \\
\text { (misalnya memparafrasekan puisi menjadi } \\
\text { karangan bebas }\end{array}$ \\
\hline 2.2Mencontohkan & $\begin{array}{l}\text { Mengilustrasikan } \\
\text { Memberi contoh }\end{array}$ & $\begin{array}{l}\text { Menemukan contoh atau ilustrasi tentang } \\
\text { konsep atau prinsip (misalnya memberi } \\
\text { contoh tentang aliran-aliran seni lukis) }\end{array}$ \\
\hline $\begin{array}{l}\text { 2.3Mengklasifika- } \\
\text { sikan }\end{array}$ & $\begin{array}{l}\text { Mengategorikan, } \\
\text { Mengelompokkan }\end{array}$ & $\begin{array}{l}\text { Menentukan sesuatu dalam satu kategori } \\
\text { (misalnya mengklasifikasikan hewan-hewan } \\
\text { bertulang belakang) }\end{array}$ \\
\hline 2.4Merangkum & $\begin{array}{l}\text { Mengabstraksi } \\
\text { Menggeneralisasi }\end{array}$ & $\begin{array}{l}\text { Mengabstraksikan tema umum atau poin-poin } \\
\text { pokok (misalnya menulis ringkasan pendek } \\
\text { tentang peristiwa-peristiwa yang ditayangkan } \\
\text { di televisi) }\end{array}$ \\
\hline 2.5 Menyimpulkan & $\begin{array}{l}\text { Menyarikan, } \\
\text { Mengesktrapolasi, } \\
\text { Menginterpolasi, } \\
\text { Memprediksi }\end{array}$ & $\begin{array}{l}\text { Membuat kesimpulan yang logis dari } \\
\text { informasi yang diterima (misalnya dalam } \\
\text { belajar bahasa Inggris, menyimpulkan tata } \\
\text { bahasa berdasarkan contohnya }\end{array}$ \\
\hline $\begin{array}{l}\text { 2.6Memban- } \\
\text { dingkan }\end{array}$ & $\begin{array}{l}\text { Mengontraskan, } \\
\text { Memetakan, } \\
\text { Mencocokkan }\end{array}$ & $\begin{array}{l}\text { Menentukan hubungan antara dua ide, dua } \\
\text { objek, dan semacamnya (misalnya, } \\
\text { membandingkan peristiwa-peristiwa sejarah } \\
\text { dengan keadaan sekarang) }\end{array}$ \\
\hline 2.7Menjelaskan & Membuat model & $\begin{array}{l}\text { Membuat model sebab - akibat dalam sebuah } \\
\text { sistem (misalnya, menjelaskan sebab-sebab } \\
\text { terjadinya peristiwa-peristiwa penting pada } \\
\text { abad ke } 18 \text { di Indonesia }\end{array}$ \\
\hline \multicolumn{3}{|c|}{$\begin{array}{l}\text { 3. Mengaplikasikan - Menerapkan atau menggunakan suatu prosedur dalam keadaan } \\
\text { tertentu }\end{array}$} \\
\hline 3.1 Mengeksekusi & Melaksanakan & $\begin{array}{l}\text { Menerapkan gaya gravitasi dalam kehidupan } \\
\text { sehari-hari }\end{array}$ \\
\hline $\begin{array}{l}\text { 3.2 Mengim- } \\
\text { plementasikan }\end{array}$ & Menggunakan & $\begin{array}{l}\text { Menerapkan suatu prosedur pada tugas yang } \\
\text { tidak familier (misalnya, menggunakan } \\
\text { Hukum Newton kedua pada konteks yang } \\
\text { tepat) }\end{array}$ \\
\hline
\end{tabular}




\begin{tabular}{|c|c|c|}
\hline $\begin{array}{l}\text { Kategori dan } \\
\text { Proses Kognitif }\end{array}$ & Nama-Nama Lain & Definisi dan Contoh \\
\hline \multicolumn{3}{|c|}{$\begin{array}{l}\text { 4. Menganalisis - Memecah-mecah materi jadi bagian-bagian penyusunnya dan } \\
\text { menentukan hubungan-hubungan antar bagian itu dan hubungan antara bagian-bagian } \\
\text { tersebut dengan keseluruhan struktur atau tujuan }\end{array}$} \\
\hline 4.1 Membedakan & $\begin{array}{l}\text { Menyendirikan, } \\
\text { Memilah, } \\
\text { Memfokuskan, } \\
\text { Memilih }\end{array}$ & $\begin{array}{l}\text { Membedakan bagian materi pelajaran yang } \\
\text { relevan dan tidak relevan, (membedakan } \\
\text { antara bilangan prima dan bukan bilangan } \\
\text { prima dalam matematika) }\end{array}$ \\
\hline $\begin{array}{l}\text { 4.2Mengor- } \\
\text { ganisasi }\end{array}$ & $\begin{array}{l}\text { Menemukan } \\
\text { koherensi, } \\
\text { Memadukan, } \\
\text { Membuat garis } \\
\text { besar, } \\
\text { Mendeskripsikan } \\
\text { peran, } \\
\text { Menstrukturkan }\end{array}$ & $\begin{array}{l}\text { Menentukan bagaimana elemen-elemen } \\
\text { bekerja atau berfungsi dalam sebuah struktur } \\
\text { (misalnya, menyusun bukti-bukti dalam cerita } \\
\text { sejarah menjadi bukti-bukti yang mendukung } \\
\text { dan menentang suatu penjelasan historis) }\end{array}$ \\
\hline $\begin{array}{l}\text { 4.3 Mengatri- } \\
\text { busikan }\end{array}$ & Mendekonstruksi & $\begin{array}{l}\text { Menentukan sudut pandang, bias, nilai, atau } \\
\text { maksud dibalik materi pelajaran (misalnya } \\
\text { menunjukkan sudut pandang penulis suatu } \\
\text { cerita berdasarkan latar belakang pendidikan } \\
\text { penulis tersebut) }\end{array}$ \\
\hline \multicolumn{3}{|c|}{ 5. Mengevaluasi - Mengambil keputusan berdasarkan kriteria atau standar } \\
\hline 5.1 Memeriksa & $\begin{array}{l}\text { Mengoordinasi, } \\
\text { Mendeteksi, } \\
\text { Memonitor, } \\
\text { Menguji }\end{array}$ & $\begin{array}{l}\text { Menemukan kesalahan dalam suatu proses } \\
\text { atau produk; menemukan efektivitas suatu } \\
\text { prosedur yang sedang dipraktikkan (misalnya } \\
\text { memeriksa apakah kesimpulan seseorang } \\
\text { sesuai dengan data-data pengamatan atau } \\
\text { tidak) }\end{array}$ \\
\hline 5.2Mengkritik & Menilai & $\begin{array}{l}\text { Menemukan inkonsistensi antara suatu } \\
\text { produk dan kriteria eksternal; menentukan } \\
\text { apakah suatu produk memiliki konsistensi } \\
\text { eksternal, menemukan ketepatan suatu } \\
\text { prosedur untuk menyelesaikan masalah } \\
\text { (misalnya, menentukan satu metode dari dua } \\
\text { metode untuk menyelesaikan suatu masalah) }\end{array}$ \\
\hline \multicolumn{3}{|c|}{$\begin{array}{l}\text { 6. Mencipta - Memadukan bagian-bagian untuk membentuk sesuatu yang baru dan } \\
\text { koheren atau untuk membuat suatu produk yang orisinal }\end{array}$} \\
\hline 6.1 Merumuskan & Membuat hipotesis & $\begin{array}{l}\text { Membuat hipotesis-hipotesis berdasarkan } \\
\text { kriteria (misalnya membuat hipotesis tentang } \\
\text { sebab-sebab terjadinya gempa bumi) }\end{array}$ \\
\hline 6.2Merencanakan & Mendesain & $\begin{array}{l}\text { Merencanakan prosedur untuk menyelesaikan } \\
\text { suatu tugas (misalnya merencanakan proposal } \\
\text { penelitian tentang topik sejarah Candi } \\
\text { Borobudur) }\end{array}$ \\
\hline 6.3Memproduksi & Mengonstruksi & $\begin{array}{l}\text { Menciptakan suatu produk (misalnya } \\
\text { membuat habitat untuk spesies tertentu demi } \\
\text { suatu tujuan) }\end{array}$ \\
\hline
\end{tabular}




\section{Kesimpulan}

Taksonomi ialah klasifikasi atau pengelompokan benda menurut ciri-ciri tertentu. Taksonomi dalam bidang pendidikan, digunakan untuk klasifikasi tujuan instruksional; ada yang menamakannya tujuan pembelajaran, tujuan penampilan, atau sasaran belajar. Taksonomi tujuan instruksional ialah adanya hierarki yang dimulai dari tujuan instruksional pada jenjang terendah sampai jenjang tertinggi. Dengan kata lain, tujuan pada jenjang yang lebih tinggi tidak dapat dicapai sebelum tercapai tujuan pada jenjang di bawahnya. Taksonomi Bloom ranah kognitif merupakan salah satu kerangka dasar untuk pengkategorian tujuan-tujuan pendidikan, penyusunan tes, dan kurikulum. Tingkatan taksonomi Bloom yakni: (1) pengetahuan (knowledge); (2) pemahaman (comprehension); (3) penerapan (application); (4) analisis (analysis); (5) sintesis (synthesis); dan (6) evaluasi (evaluation). Tingkatan-tingkatan dalam taksonomi tersebut telah digunakan hampir setengah abad sebagai dasar untuk penyusunan tujuan-tujuan pendidikan, penyusunan tes dan kurikulum.

Revisi dilakukan terhadap Taksonomi Bloom, yakni perubahan dari kata benda (dalam Taksonomi Bloom) menjadi kata kerja (dalam taksonomi revisi). Perubahan ini dibuat agar sesuai dengan tujuan-tujuan pendidikan. Tujuan-tujuan pendidikan mengindikasikan bahwa siswa akan dapat melakukan sesuatu (kata kerja) dengan sesuatu (kata benda). Revisi dilakukan oleh Kratwohl dan Anderson, taksonomi menjadi: (1) mengingat (remember); (2) memahami (understand); (3) mengaplikasikan (apply); (4) menganalisis (analyze); (5) mengevaluasi (evaluate); dan (6) mencipta (create). 


\section{DAFTAR RUJUKAN}

Alexander, P., Schallert, D., Hare, V. 1991. Coming to Terms: How Researcher in Learning and Literacy Talk about Knowledge. Review of Educational Research, 61: $315-343$.

Anderson, L.W. 1983. The Architecture of Cognition. Cambridge: Harvard University Press.

Anderson, L.W., dan Krathwohl, D.R. 2001. A Taxonomy for Learning, Teaching, and Assesing: A Revision of Bloom's Taxonomy of Educatioanl Objectives. New York: Addison Wesley Longman, Inc.

Bloom, B.S., Engelhart, M.D., Furst, E.J., Hill, W.H., dan Krathwohl, D.R. 1956. The Taxonomy of Educational Objectives The Classification of Educational Goals, Handbook I: Cognitive Domain. New York: David McKay.

Bransford, J.D., Brown, A.L., dan Cooking, R.R. 1999. How People Learn: Brain, Mind, Experience, and School. Washington DC: National Academy Press.

Chung, B.M. 1994. The Taxonomy in the Republic of Korea. In Anderson, L.W., dan Sosiak, L.A (Eds), Bloom's Taxonomy: A Forty-year Retrospective, Ninety-third Yearbook of the National Society for the Study of Education (hlm. 363 - 173). Chicago: University of Chicago Press.

deJong, T., dan Ferguson-Hessler, M. 1996. Types and Qualities of Knowledge. Educational Psychologist, 31: 105 - 113.

Dochy, F., dan Alexander, P. 1995. Mapping Prior Knowledge: A Framework of Discution among Researcher. European Journal of Psychology in Education, 10: 224 - 242.

Flavell, J. 1979. Metacognition and Cognitive Monitoring: A New Area of Cognitive Developmental Inquiry. American Psychologist, 34: 906 - 911.

Heer, R. 2012. A Model of Learning Objectives (Online). (www.celt.iastate.edu/teaching/RevisedBlooms1.html, diakses 8 Februari 2012).

Lewy, A., dan Bathory, Z. 1994. The Taxonomy of Educational Objectives ind Continental Europe, the Mediterranean, and the Middle East. In Anderson, L.W., dan Sosiak, L.A (Eds), Bloom's Taxonomy: A Forty-year Retrospective, Ninety-third Yearbook of the National Society for the Study of Education (hlm. 146 - 163). Chicago: University of Chicago Press. 
Paris, S., Lipson, M., dan Wixson, K. 1983. Becoming a Strategic Reading. Contemporary Educational Psycilogy, 8: 293 - 316.

Postlethwaite, T. N. 1994. Validity vs Utility: Personal Experiences with the Taxonomy. In Anderson, L.W., dan Sosiak, L.A (Eds), Bloom's Taxonomy: A Forty-year Retrospective, Ninety-third Yearbook of the National Society for the Study of Education (hlm. 174 - 180). Chicago: University of Chicago Press.

Rohwer, W.D., dan Sloane, K. 1994. Psycological Perspectives. In Anderson, L.W., dan Sosiak, L.A (Eds), Bloom's Taxonomy: A Forty-year Retrospective, Ninety-third Yearbook of the National Society for the Study of Education (hlm. 41 - 63). Chicago: University of Chicago Press.

Sternberg, R. 1985. Beyond IQ: A Triarchic Theory of Human Intelligence. New York: Cambridge University Press.

Tyler, R.W. 1994. Basic Principles of Curriculum and Intruction. Chicago: University of Chicago Press.

Zimmerman, B.J., dan Schunk, D. H. 1998. Self Regulated Learning: from Teaching to Self Reflective Practice. New York: Guilford Press. 